Journal of New Results in Science
https://dergipark.org.tr/en/pub/jnrs
Research Article
Open Access

\title{
Molecular and morphological investigation of Cortinarius bulliardii from Tokat (Turkey)
}

\author{
Meryem Şenay Şengül Demirak ${ }^{1}$ (D) İbrahim Türkekul² (1)
}

\begin{abstract}
Keywords:
Abstract - A macrofungi species, Cortinarius bulliardii is collected from Tokat city province

Cortinariaceae, during field trips in 2019. It has a smooth, finely light fibrous, brownish-red pileus, whitish to

ITS, light lilac-brownish flesh, broadly ellipsoidal spores, light brown when young, then dark brown

$L S U$, lamellae with age. In addition to morphological analysis, molecular sequence data based on the ITS and LSU rDNA gene regions indicated that the studied species is Cortinarius bulliardii.
\end{abstract}

Phylogenetics,

Turkey,

Subject Classification (2020):

\section{Introduction}

The genus Cortinarius (Pers.) Gray is the largest genus of the Agaricales in the world [1]. Species of Cortinarius have a worldwide distribution and they form ectomycorrhizal associations with some coniferous and broad-leaved trees [2-4].

Species identification in this genus based solely on morphological analysis is very confusing and may lead to false interpretations. Thus, molecular studies are important to better identify and name Cortinarius species correctly. The nuclear ribosomal internal transcribed spacer (ITS) is a universal barcode marker for fungal taxonomic studies [5]. It is also the most reliable marker to solve species delimitation problems of the genus Cortinarius [6]. Additionally, other marker regions, such as nuclear ribosomal large subunit (LSU) or largest subunits of RNA polymerase II (RPB1, RPB2) may also be used to better resolve infrasubgeneric relationship within the Cortinarius species [3].

More than 130 species belonging to this genus have been identified in Turkey [7]. However, molecular studies are lacking in most of these studies. A few species from this genus have been studied including molecular data, some of which are Cortinarius conicoumbonatus [2], Cortinarius caerulescens [8], Cortinarius rapaceoides [9], Cortinarius rufo-olivaceus [10] and Cortinarius lilacinovelatus [11]. Cortinarius bulliardii (Pers.) Fr. / çizik örümcekmantarı has been previously reported as list from

\footnotetext{
${ }^{1}$ senay.sengul@gop.edu.tr (Corresponding Author); 2ibrahim.turkekul@gop.edu.tr

1Department of Molecular Biology and Genetics, Faculty of Arts \& Sciences, Tokat Gaziosmanpasa University, Tokat, Turkey

${ }^{2}$ Department of Biology, Faculty of Arts \& Sciences, Tokat Gaziosmanpasa University, Tokat, Turkey

Article History: Received: 12 Jul 2021 - Accepted: 26 Oct 2021 - Published: 31 Dec 2021
} 
Trabzon/Akçaabat $[7,12]$ and Çanakkale/Bayramiç [13] regions of Turkey. However, these studies lack both molecular data and morphological description of this species.

Cortinarius bulliardii (Pers.) Fr. was first described by Fries [14]. It is characterized with a flesh, rounded, smooth and reddish-colored pileus; bulbous, cinnabar-colored stipe; whitish flesh and reddish brown at the base of the stipe; lamella broad and reddish-brown. Cortinarius bulliardii is reported from different regions of Europe, widely distributed within the temperate-Mediterranean Europe, and from America, Asia and north Africa $[15,16]$. It usually found in deciduous forests (Corylus, Quercus, Tilia, Fagus) on calcareous soil [4, 17].

In this study, we provide description of $C$. bulliardii from Tokat city province (Turkey) based on morphological features and molecular phylogenetic analyses of the ITS and LSU gene regions. With the combination of morphological and molecular analyses, we shed light into the Cortinarius distribution in this continent and contribute significantly to the Cortinarius mycobiota of Turkey.

\section{Materials and methods}

\subsection{Morphological analysis}

The fungal specimens were collected from Tokat province during field trips in December 2019. Ecological and macroscopic features such as sizes of cap and stipe, color, odor, color change upon handle or bruising were noted in the field. Then, specimens were brought to the laboratory for chemical tests and microscopic examinations. Microscopic observations were made from dried fungarium specimens mounted in distilled water, Lactophenol, Congo red, or $\mathrm{KOH}$ using a light microscope. Identification of the samples was performed with the help of the literature [18]. The identified collection was deposited in the Fungarium of Department of Biology, Tokat Gaziosmanpaşa University (GOPUF).

\subsection{Molecular analysis}

Genomic DNA was isolated from lamella of the macrofungi using the ZR Fungal/Bacterial DNA MiniPrep kit (Zymo Research Irvine, CA, USA) as described by the manufacturer's protocol. To amplify ITS1-5.8SITS2 and 28S LSU gene regions, primer pairs ITS4: 5'-TCCTCCGCTTATTGATATGC-3'/ITS5: 5'GGAAGTAAAAGTCGTAACAAGG-3' [19] and LROR: 5': ACCCGCTGAACTTAAGC-3'/LR5: 5': TCCTGAGGGAAACTTCG-3' [20] were used. The DNA was amplified in a $30 \mu$ l volume mixture using Dream Taq DNA polymerase (Thermo) using the conditions described previously [11]. PCR amplifications were verified by using $1 \%$ agarose gel electrophoresis. PCR products were sequenced from both ends using forward and reverse primers (BM Labosis Inc., Ankara).

Chromatograms were checked for errors for each sequence and a final sequence for ITS and LSU regions were generated for further analysis. Homology based searches using Basic Local Alignment Search Tool (BLAST) program was performed to identify best matches. Accordingly, representative ITS and LSU sequences from other Cortinarius species were retrieved from GenBank for phylogenetic analysis. Sequence analysis, such as sequence alignments and phylogenetic trees for each genomic region were determined using MEGA 6.0 [21]. Phylogenetic trees were constructed using the maximum likelihood (ML) method where Tamura-Nei model [22] was used to construct the ML tree with bootstrap support of 1000 replicates and default settings. The bootstrap support values $\geq 50 \%$ were marked on the branches of the tree. 


\section{Results and Discussion}

\subsection{Taxonomy}

\section{Fungi}

\section{Basidiomycota}

\section{Cortinariaceae}

Cortinarius bulliardii (Pers.) Fr., Epicrisis Systematis Mycologici: 282 (1838) (Figure 1)

\section{Macroscopic and microscopic features:}

Pileus 50-80 $\mathrm{mm}$ in diameter, hemispherical in youth, then conical to broad bell-shaped, wavy in age, with a long-curled edge. On the surface smooth, finely light fibrous, brownish-red, hygrophane (Figure 1a). Flesh whitish to light lilac-brownish, slightly gray-brown marbled, unchanged by oxidation, odor weak, unpleasant, taste mild, radish. Lamellae in number 45-57, attached to the friction, light brown in youth, then dark brown. Stipe $60-110 \times 6-10 \mathrm{~mm}$, at the base up to $25 \mathrm{~mm}$ wide. Surface dry, fibrous, grayish-white in the upper part, noticeably in the lower half towards the base orange (Figure 1a). Spores broadly ellipsoidal, on the surface with warty, coarse, and low ornamentation, 8-11 $\times 5-7 \mu \mathrm{m}$, (Figure 1b). Basidia tetrasporic, clavate, $25-35 \times 8.5-11 \mu \mathrm{m}$, with basal clamp (Figure 1c). Terminal cells 3.5-10 $\mu \mathrm{m}$ across, hyaline to reddish-brown and lightly encrusted in places septa with clamps (Figure 1d).

Specimen examined: TURKEY, Tokat province, Akbelen village, in Quercus spp. forests, on calcareous soil. 40²7'55"N, 36³8'24"E, 1079 m, 08.12.2019, GOPUF HIS-23, GenBank MZ291672 and MZ291697.
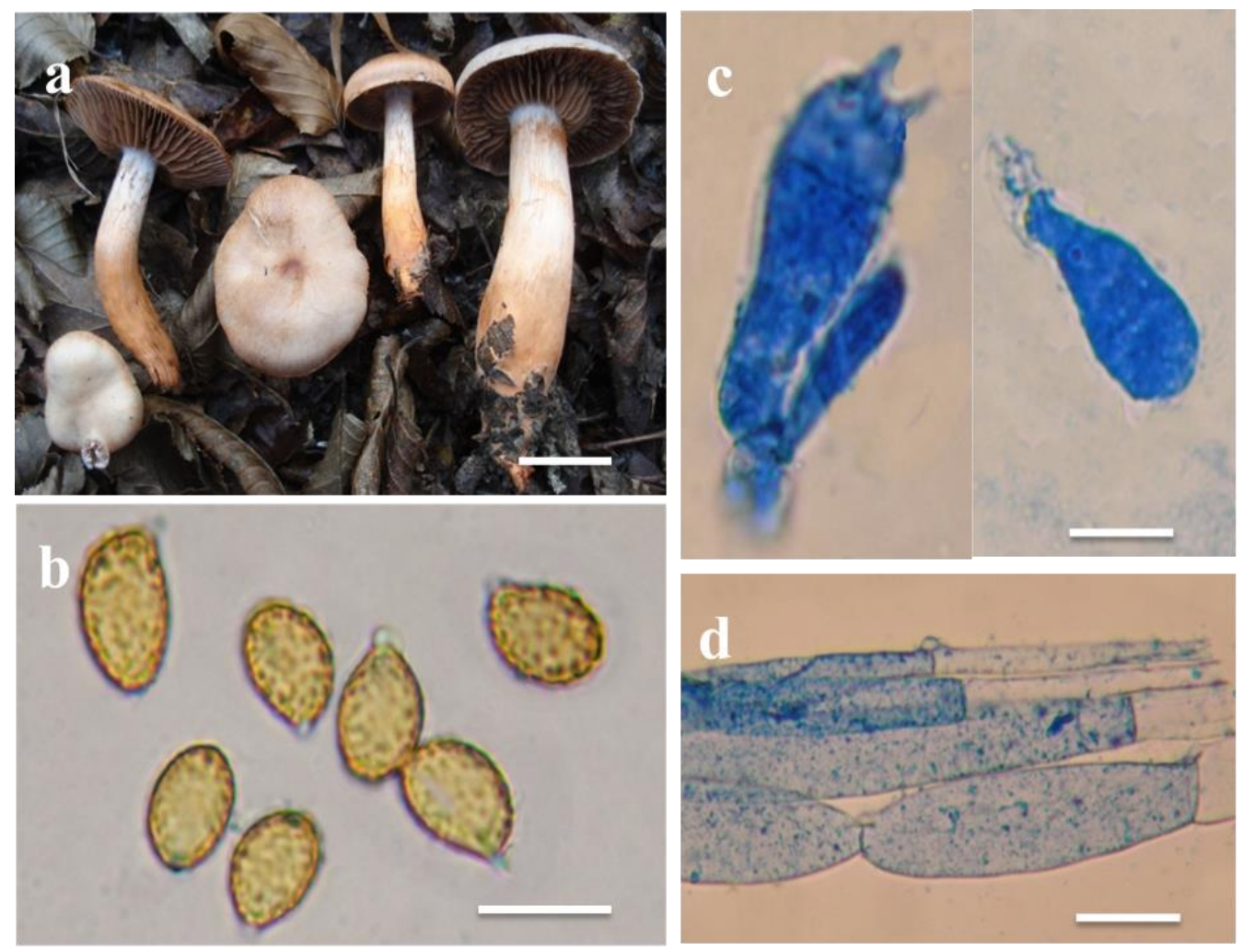

Figure 1. Cortinarius bulliardii (Collection HIS-23): a- basidiomata in situ, b- basidiospores, c- basidia, $\mathrm{d}$ - pileipellis (Scale bars: $\mathrm{a}=30 \mathrm{~mm}$; $\mathrm{b}-\mathrm{d}=10 \mu \mathrm{m}$ ). 
Fries [14] indicated that Cortinarius colus Fr. is similar to Cortinarius bulliardii (Pers.) Fr. although it has a much pale and decurrent lamellae, a narrow stipe and it is a much smaller fungus when compared to $C$. bulliardii. Moreover, Cortinarius colus is a species found in pine forests while C. bulliardii is normally associated with Corylus, Quercus and Fagus. Other closely related species to C. bulliardii are $C$. cinnabarinus Fr. and $C$. coccineus Reumaux, which are mostly found in mixed forests of hardwoods in Europe [23]. These two species are regarded as the orange-to-orange red species of subgenus Telamonia [23]. Cortinarius cinnabarinus has a cinnabar red to brownish red whole fruiting body, brownish red flesh, and smaller spores, while $C$. bulliardii is recognized by saturated red brown cap, cinnabar red base of its stipe, grayish brown flesh and larger spores [17]. Cortinarius coccineus also differs from $C$. bulliardii by its dull reddish to dark brown or blackish lamellae, strongly orange red stipe, and smaller spores $[23,24]$.

\subsection{Molecular Phylogeny}

About $600 \mathrm{bp}$ ITS and $881 \mathrm{bp}$ LSU genomic rDNA sequences were determined from the studied sample and the sequences were deposited at GenBank under the accession numbers, MZ291672 and MZ291697, respectively.

Blast search with ITS sequence showed high sequence similarity (98\%) with C. bulliardii (GenBank No. JX114942) from Sweden. Blast search with LSU also gave a high sequence similarity (100 \%) to $C$. bulliardii (GenBank No. AF388782). Other sequences that showed significant similarity with our ITS and LSU query sequences were also retrieved for phylogenetic analysis. Maximum likelihood (ML) tree was constructed separately for each gene region (Figure 2 and Figure 3). Each tree clearly showed a well-supported clade for $C$. bulliardii species from different locations. In the ITS tree, $C$. cinnabarinus and $C$. coccineus form a clade with $C$. bulliardii, while $C$. californicus, $C$. hesleri and $C$. coracis form a distant clade to $C$. bulliardii (Figure 2). Cortinarius neosanguineus was used as the outgroup species to root the trees.

Molecular phylogenetic analysis showed that $C$. cinnabarinus and $C$. bulliardii are monophyletic and $C$. coccineus was basal to the clade including $C$. bulliardii and $C$. cinnabarinus. Cortinarius hesleri is the distant species to $C$. bulliardii but more closely related to $C$. californicus. Although $C$. cinnabarinus is genetically the most closely related species to $C$. bulliardii, they have distinctive morphological features as mentioned above. Our phylogenetic results are also in agreement with that of Ammirati et al. [23]. 


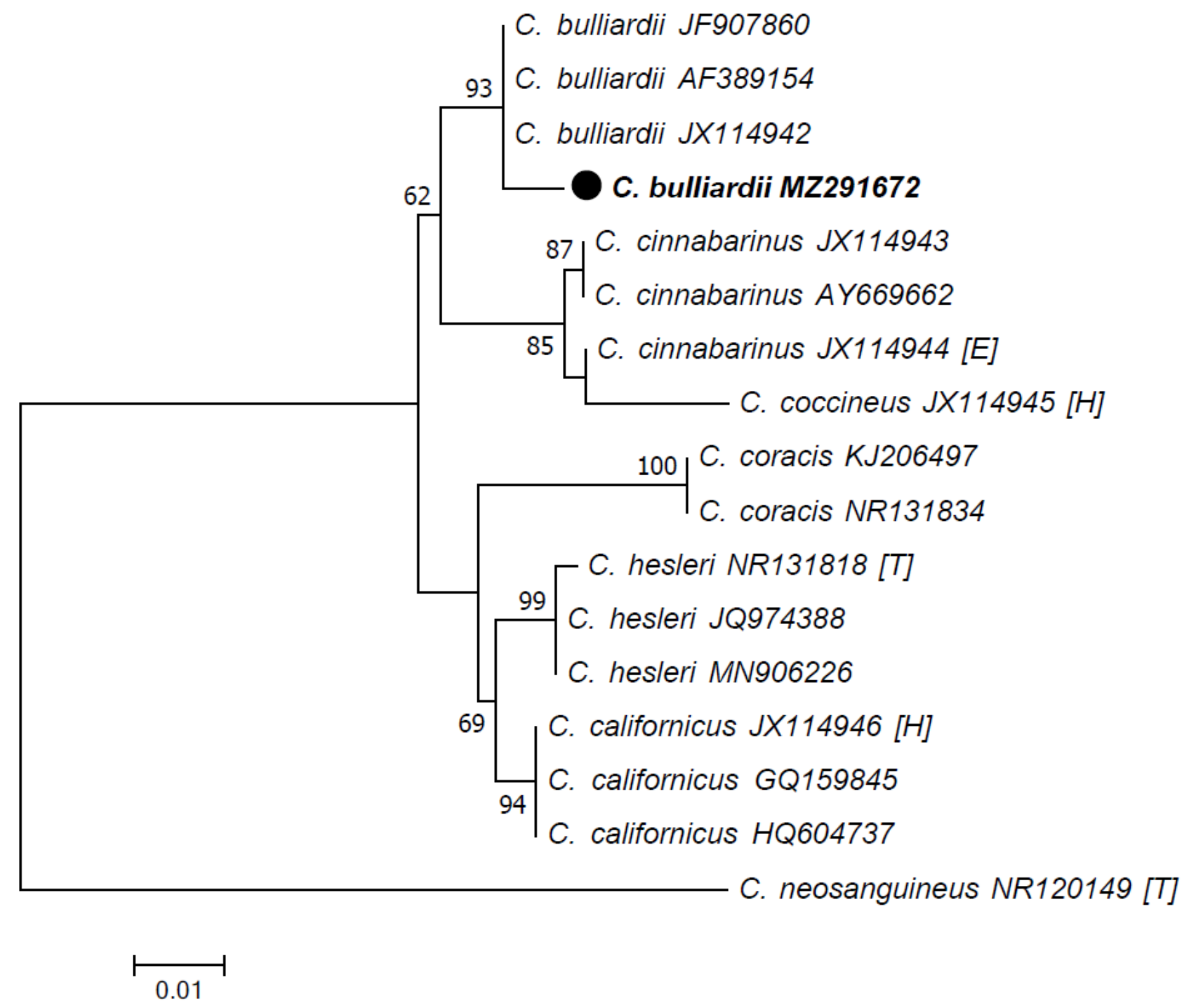

Figure 2. ITS sequence-based phylogeny of Cortinarius bulliardii using ML method. The studied specimen is indicated with black circle and in bold. Cortinarius neocanguineus was the outgroup species. Bootstrap support values $\geq 50 \%$ from ML analysis were shown on the branches. Bar indicates 0.01 expected change per site per branch. E: epitype, $\mathrm{H}$ : holotype, T: type 


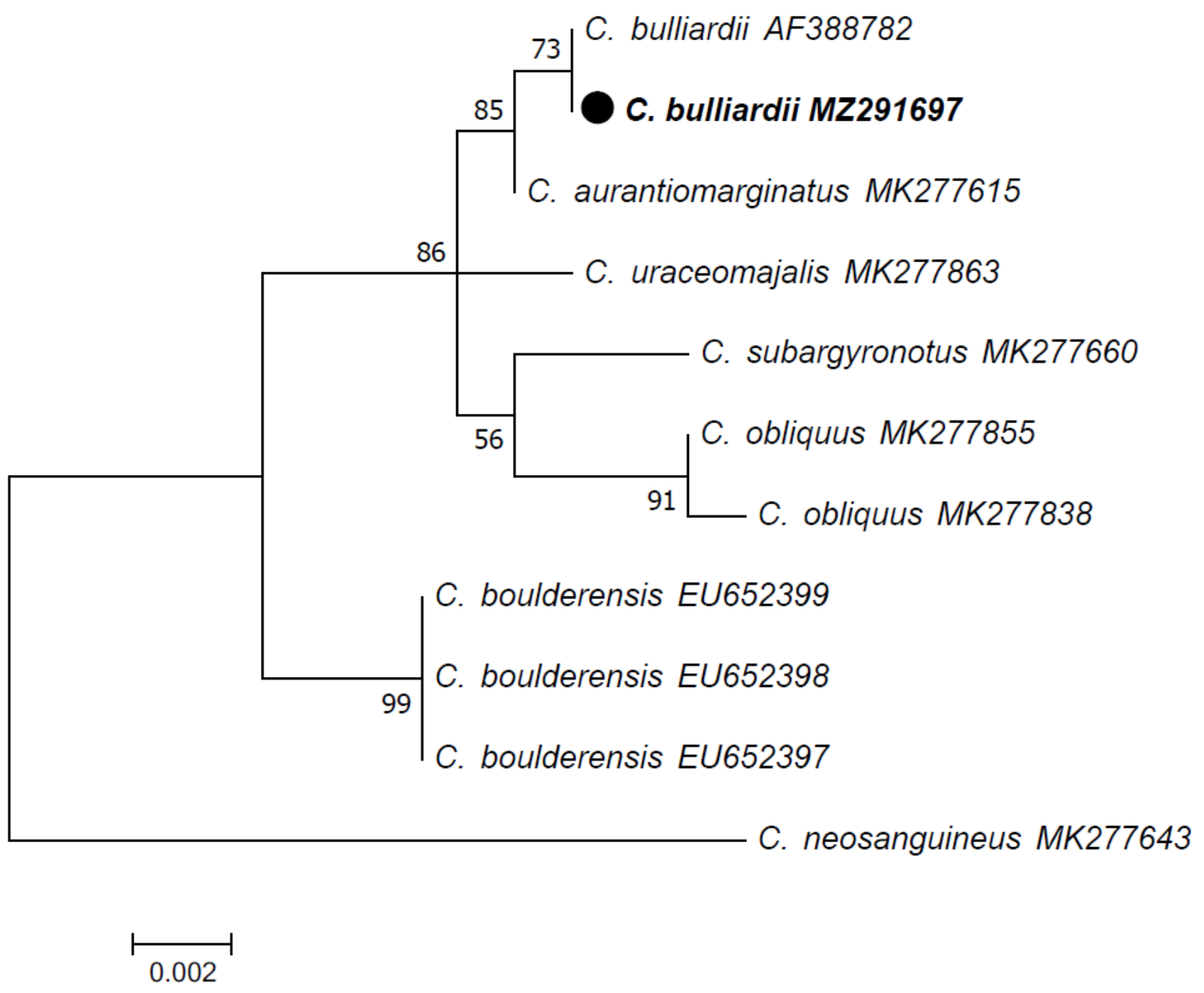

Figure 3. LSU sequence-based phylogeny of Cortinarius bulliardii using ML method. The studied specimen is indicated with black circle and in bold. Cortinarius neocanguineus was the outgroup species. Bootstrap support values $\geq 50 \%$ from ML analysis were shown on the branches. Bar indicates 0.002 expected change per site per branch.

\section{Conclusion}

Cortinarius bulliardii is described from Tokat city province, Turkey, including both its morphological features and molecular data. The phylogenetic relationship and biogeographical patterns of $C$. bulliardii are discussed. We hope more ITS barcoding data are produced for other Cortinarius species from Turkey to better understand speciation in the genus Cortinarius and their distribution in this continent which has high biological diversity.

\section{Author Contributions}

All authors contributed equally to this work. They all read and approved the final version of the manuscript. 


\section{Conflicts of Interest}

The authors declare no conflict of interest.

\section{Acknowledgement}

This work was supported by the Office of Scientific Research Projects Coordination at Tokat Gaziosmanpaşa University, Grant number: 2019/87.

\section{References}

[1] P. M. Kirk, P. F. Cannon, D. W. Minter, J. A. Stalpers, Dictionary of the fungi, 10th edn. CAB International, Wallingford, UK, 2008.

[2] E. Sesli, K. Liimatainen, Cortinarius conicoumbonatus (Cortinarius subgen. Telamonia sect. Hinnulei): a new species from spruce-beech forests of the East Black Sea Region of Turkey, Turkish Journal of Botany, 42, (2018) 327-334.

[3] K. Soop, B. Dima, J. A. Cooper, D. Park, B. Oertel, A phylogenetic approach to a global supraspecific taxonomy of Cortinarius (Agaricales) with an emphasis on the southern mycota, Persoonia, 42, (2019) 261-290.

[4] K. Liimatainen, T. Niskanen, B. Dima, J. F. Ammirati, P. M. Kirk, I. Kytövuori, Mission impossible completed: unlocking the nomenclature of the largest and most complicated subgenus of Cortinarius, Telamonia, Fungal Diversity, 104(1), (2020) 291-331.

[5] C. L. Schoch, K. A. Seifert, S. Huhndorf, V. Robert, J. L. Spouge, C. A. Levesque, W. Chen, Fungal Barcoding Consortium, Nuclear ribosomal internal transcribed spacer (ITS) region as a universal DNA barcode marker for Fungi, Proceedings of the National Academy of Sciences USA, 109, (2012) 6241-6246.

[6] S. Garnica, M. E. Schön, K. Abarenkov, K. Riess, K. Liimatainen, T. Niskanen, B. Dima, K. Soop, T. G. Frøslev, T. S. Jeppesen, U. Peintner, R. Kuhnert-Finkernagel, T. E. Brandrud, G. Saar, B. Oertel, J. F. Ammirati, Determining threshold values for barcoding fungi: lessons from Cortinarius (Basidiomycota), a highly diverse and widespread ectomycorrhizal genus, FEMS Microbiology Ecology, 92 (4), (2016) fiw045.

[7] E. Sesli , A. Asan, F. Selçuk (eds.) Ö. Abacı Günyar, I. Akata, H. Akgül, S. Aktaş, S. Alkan, H. Allı, H. Aydoğdu, D. Berikten, K. Demirel, R. Demirel, H. H. Doğan, M. Erdoğdu, C. C. Ergül, G. Eroğlu, G. Giray, A. Halikî Uztan, Ş. Kabaktepe, D. Kadaifçiler, F. Kalyoncu, İ. Karaltı, G. Kaşık, A. Kaya, A. Keleş, S. Kırbağ, M. Kıvanç, İ. Ocak, S. Ökten, E. Özkale, C. Öztürk, M. Sevindik, B. Şen, İ. Şen, İ. Türkekul, M. Ulukapı, Ya. Uzun, Yu. Uzun, A. Yoltaş, The Checklist of Fungi of Turkey, Ali Nihat Gökyiğit Vakfı Yayını, İstanbul, 2020.

[8] A. Kalmer, İ. Acar, A. Dizkırıcı Tekpınar, Phylogenetic and taxonomic studies on Cortinarius caerulescens (Schaeff.) Fr. a new record for Turkish mycota, The Journal of Fungus 10, (2019) 816.

[9] M. S. Sengul Demirak, H. Isik, Cortinarius rapaceoides, a new record for Turkey, Mycotaxon, 135, (2020) 559-568.

[10] M. S. Şengül Demirak, H. Ișık, İ. Türkekul, İ., Morphological and Molecular Phylogeny of Cortinarius rufo-olivaceus (Pers.) Fr. (subgenus Phlegmacium sect. Calochroi) Collected from Tokat Region. KSU Journal of Agriculture and Nature, 23(3), (2020) 600-605.

[11] M. S. Sengul Demirak, I. Turkekul, Cortinarius lilacinovelatus (Agaricales, Cortinariaceae)-A new record for Turkey, Nova Hedwigia, (2021) 217-227. 
[12] S. Baydar, E. Sesli, The macromycetes determined in Akçaabat District of Trabzon Province, Turkish Journal of Botany 18, (1994) 99-101.

[13] N. Adanacıoğlu, Ü. Yıldız, O. Erdinç, L. Aykas, A. Tan, T. Taylan, Türkiye makromantarı genetik kaynakları I. Ege Bölgesi, Anadolu Ege Tarımsal Araştırma Enstitüsü Dergisi, 26(1), (2016) 46-61.

[14] E. M. Fries, Epicrisis Systematis Mycologici, 282, Uppsala, Sweden, 1838.

[15] T. Tejklová, J. Kramoliš, Pavučinec Bulliardův-Cortinarius bulliardii, nápadný druh teplomilných dubohabřin, Mykologický Sborník 3, 2016.

[16] G. J. Krieglsteiner, A. Gminder, Die GroGpilze Baden-Wiirttembergs. Band 5: Standerpilze: Blatterpilze III. Eugen Ulmer KG, Stuttgart, 671 p., 2010.

[17] T. Niskanen, I. Kytövuori, E. Bendiksen, K. Bendiksen, T. E. Brandrud, T. G. Frøslev, K. Høiland, T. S. Jeppesen, K. Liimatainen, H. Lindström, Cortinarius (Pers) Gray. In: Knudsen H, Vesterholt J (eds). Funga Nordica, 2nd revised edition. Agaricoid, boletoid, clavarioid, cyphelloid and gastroid genera, Nordsvamp, Copenhagen, Denmark, (2012), pp 762-763.

[18] J. Breitenbach, F. Kränzlin, Fungi of Switzerland (Vol. 5), Lucerne, Switzerland: Verlag Mykologia, 2000.

[19] T. J. White, T. Bruns, S. J. Lee, J. Taylor, Amplification, and direct sequencing of fungal ribosomal RNA genes for phylogenetics, In: Innis MA, Gelfand DH, Sninsky JJ, White TJ, editors. PCR protocols: a guide to methods and applications. New York, NY, USA: Academic Press, pp. 315-322, 1990.

[20] R. Vilgalys, M. Hester, Rapid genetic identification, and mapping of enzymatically amplified ribosomal DNA from several Cryptococcus species, Journal of Bacteriology, 172(8), (1990) 42384246.

[21] K. Tamura, G. Stecher, D. Peterson, A. Filipski, S. Kumar, MEGA6: molecular evolutionary genetics analysis version 6.0., Molecular Biology and Evolution, 30, (2013) 2725-2729.

[22] K. Tamura, M. Nei, Estimation of the number of nucleotide substitutions in the control region of mitochondrial DNA in humans and chimpanzees, Molecular Biology and Evolution, 10(3), (1993) 512-526.

[23] J. F. Ammirati, K. W. Hughes, K. Liimatainen, T. Niskanen, P. B. Matheny, Cortinarius hesleri from eastern North America and related species from Europe and western North America, Botany, 91(2), (2013) 91-98.

[24] A. Bidaud, P. Moënne-Loccoz, P. Reumaux. Atlas des Cortinaires, Pars VI, Èditions Fèdération mycologique Dauphiné-Savoie, France, 1994. 